TÜSİAD-KOÇ UNIVERSITY ECONOMIC RESEARCH FORUM WORKING PAPER SERIES

THE EFFECTS OF SOCIAL SECURITY TAXES AND MINIMUM WAGES ON EMPLOYMENT: EVIDENCE FROM TURKEY

Kerry L. Papps

Working Paper 1017

May 2010

TÜSİAD-KOÇ UNIVERSITY ECONOMIC RESEARCH FORUM Rumeli Feneri Yolu 34450 Sarıer/Istanbul 


\title{
The effects of social security taxes and minimum wages on employment: Evidence from Turkey
}

\author{
Kerry L. Papps*
}

\begin{abstract}
Using worker-level panel data for Turkey, this paper analyses the separate employment effects of increases in the social security taxes paid by employers and increases in the minimum wage between 2002 and 2005. Variation over time and among low-wage workers in the ratio of total labour costs to the gross wage gives rise to a natural experiment. Regression estimates indicate that a given increase in social security taxes has a larger negative effect on the probability of a worker remaining employed in the next quarter than an equal-sized increase in the minimum wage. Those who retain their jobs in the next quarter also experience a larger reduction in working hours when social security taxes increase than when the minimum wage rises. This is consistent with a situation in which workers increase effort in response to an increase in wages. Men, rural-dwellers and those under 30 are found to have the strongest overall disemployment effects in response to increases in labour costs.
\end{abstract}

\section{Introduction}

A number of studies have established a link between changes in labour costs and employment using longitudinal data on workers. Many of these have focused on the impact of minimum wages. Typically, authors use a treatment variable that is equal to the difference between a person's wage and the new minimum wage for those earning less than the latter and zero for those earning more than the new minimum wage. A key issue has been how to construct an appropriate control group. Among those studying increases in the federal minimum wage in the United States, both Linneman (1982) and Ashenfelter and Card (1981) examined the effect of increases in the minimum wage in 1973 and 1974. Whereas Linneman compared those earning less than the newly-set minimum wage with those earning higher wages (and hence unaffected by the minimum wage rise), Ashenfelter and Card also compared those earning less than the new minimum wage in covered and uncovered sectors. Currie and Fallick (1996) considered the 1980 and 1981 increases in the federal minimum using both types of control group but with fixed effects models estimated on long-term longitudinal data. Approaches similar to Linneman's have

\footnotetext{
* Nuffield College, New Road, Oxford, OX1 1NF, United Kingdom; kerry.papps@economics.ox.ac.uk. Portions of the research for this paper were completed while the author was employed as a consultant for the World Bank. The author is grateful to Gordon Betcherman and Carmen Pagés for their invaluable assistance and to Meltem Daysal and İnsan Tunalı for providing useful comments.
} 
Figure 1

Labour force indicators and production in Turkey
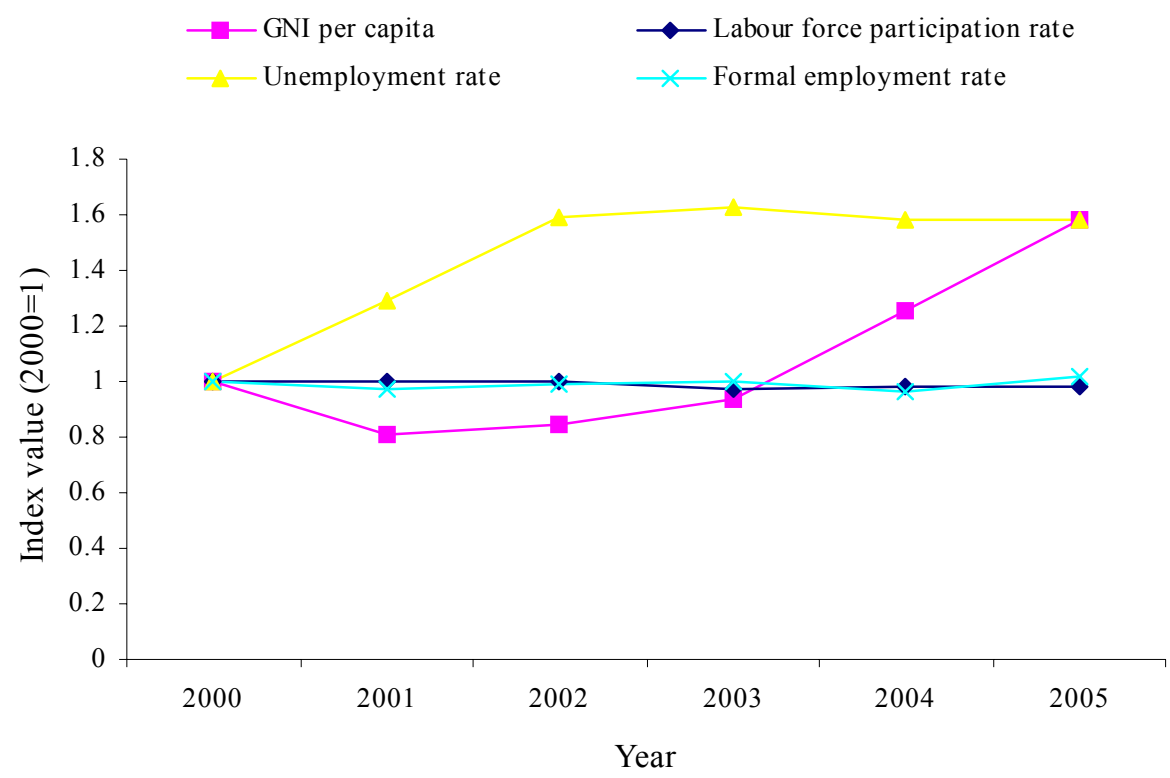

Sources: GNI per capita (current US dollars): World Bank using Atlas method; labour force participation rate, unemployment rate and formal employment rate (fraction of jobs registered with SSK): author's calculations using Household Labour Force Survey data.

also been taken in developing countries, especially in Latin America (Maloney and Nuñez Mendez (2004), Lemos (2009), Strobl and Walsh (2003)).

Studies have also looked at the effects of other policies that influence labour costs. Kramarz and Philippon (2001) analysed the employment effects of changes in the payroll tax and subsidy system (as well as the minimum wage) in France, comparing workers who were directly affected by changes in labour costs with workers who earned slightly more. Kugler et al. (2003) used a short-term panel to examine the effects of labour market reforms in Spain, which reduced payroll taxes and dismissal costs for workers on permanent contracts. Since these reforms applied only to certain demographic groups, they were able to construct a natural experiment.

Turkey experienced a low rate of job creation during the first half-decade of the $21^{\text {st }}$ century, despite strong economic growth during this period. As illustrated in Figure 1, Gross National Income per capita increased steadily between 2001 (when the Turkish financial crisis ended) and 2005, however the unemployment rate actually rose during this period and the labour force participation rate remained around 50\%. Moreover, 
among those in employment, only about one half is registered with the social security system. One possible cause of the stubbornly low employment growth is the high level of taxation on labour. Combined employer and employee contributions to finance pensions and disability insurance, health insurance, unemployment benefits and workers' compensation equal around $40 \%$ of gross wages, which is high compared to other European and OECD countries. Furthermore, a minimum wage also exists and this has increased sharply in recent years. Only two previous papers have examined the effect of changes in labour costs on employment levels in Turkey. Betcherman et al. (2010) studied the introduction of regionally-targeted employment subsidies in 1998 and found that they led to significant increases in employment among firms registered with the social security system, however much of this appeared to be the result of existing firms registering rather than the creation of new jobs. Using a structural model, Ozturk (2009) found that the presence of minimum wages, combined with inflexibility in work hours resulted in a much lower level of female of labour force participation than would otherwise have transpired.

This paper examines whether increases in social security taxes and minimum wages in recent years have had an effect on employment levels. This is done by exploiting a unique natural experiment which arises as a result of the structure of the Turkish social security system. Because there is a minimum level of social security contributions for each job, employers who hire workers at the lowest end of the wage distribution face a total labour cost that is proportionately larger than employers of workers with slightly higher wages. In addition, the minimum wage inflates the wage paid to low-skilled workers. Both social security taxes and the minimum wage impose additional costs on employers of low-wage workers; however, the government receives any tax payments whereas the worker is the beneficiary of any minimum wage rise. Hence, any differences in employment outcomes between the two policies may reflect differences in the behaviour of workers in response to changes in their wages.

Longitudinal data from the Turkish Household Labour Force Survey are used to examine whether workers affected by increases in employer social security contributions or the minimum wage have a lower probability of being employed in the following quarter. Results indicate that a one million Turkish lira (roughly US \$0.70) increase in 
labour costs arising from a minimum wage rise reduces the probability of remaining employed by $0.15 \%$, whereas the same increase in labour costs resulting from an increase in social security contributions yields a $0.20 \%$ fall in employment probability. The effect of the minimum wage becomes insignificant when the comparison group is restricted to those earning low wages, but the effect of social security taxes is even larger in this case. This result is incompatible with the basic model of labour supply and demand, which predicts that payroll taxes should have smaller employment effects than minimum wages because employers can offset taxes by reducing wage rates.

The next section provides a brief overview of the Turkish social security system. Section 3 describes the data used in the analysis and Section 4 presents the results of employment equations using the longitudinal sample of workers.

\section{Brief description of the Turkish social security tax system}

Prior to 2006, the Turkish social security system consisted of three separate institutions, each responsible for a different sector of the workforce: Sosyal Sigortalar Kurumu (SSK) for private sector workers, Emekli Sandiği (ES) for civil servants and Bağ-Kur (BK) for self-employed workers and farmers. ${ }^{1}$ SSK accounted for roughly $60 \%$ of the insured population, while ES and BK accounted for about 20\% each (Organisation for Economic Co-operation and Development (1999)). Since this study looks only at wage earners, it will focus on those covered by SSK or ES.

Under the ES system, employers and employees contributed to a single pension and health fund. During the sample period, employers contributed $20 \%$ of the gross wage; employees contributed 15\% of the gross wage before April 2003 and 16\% thereafter. Since the employer contribution rate was unchanged during the period, this group of workers will serve as one comparison group in the regression analysis. In the private sector, which is covered by SSK, both employers and employees contributed a fraction of the gross wage to a social security fund and an unemployment insurance fund. The social security fund covered a variety of forms of insurance: invalidity, old-age and death; employment injury and occupational diseases; sickness; and maternity. The employer

\footnotetext{
${ }^{1}$ Under reforms enacted in May 2006 and January 2007, the three systems were merged.
} 
Table 1

Minimum wages and social security tax parameters

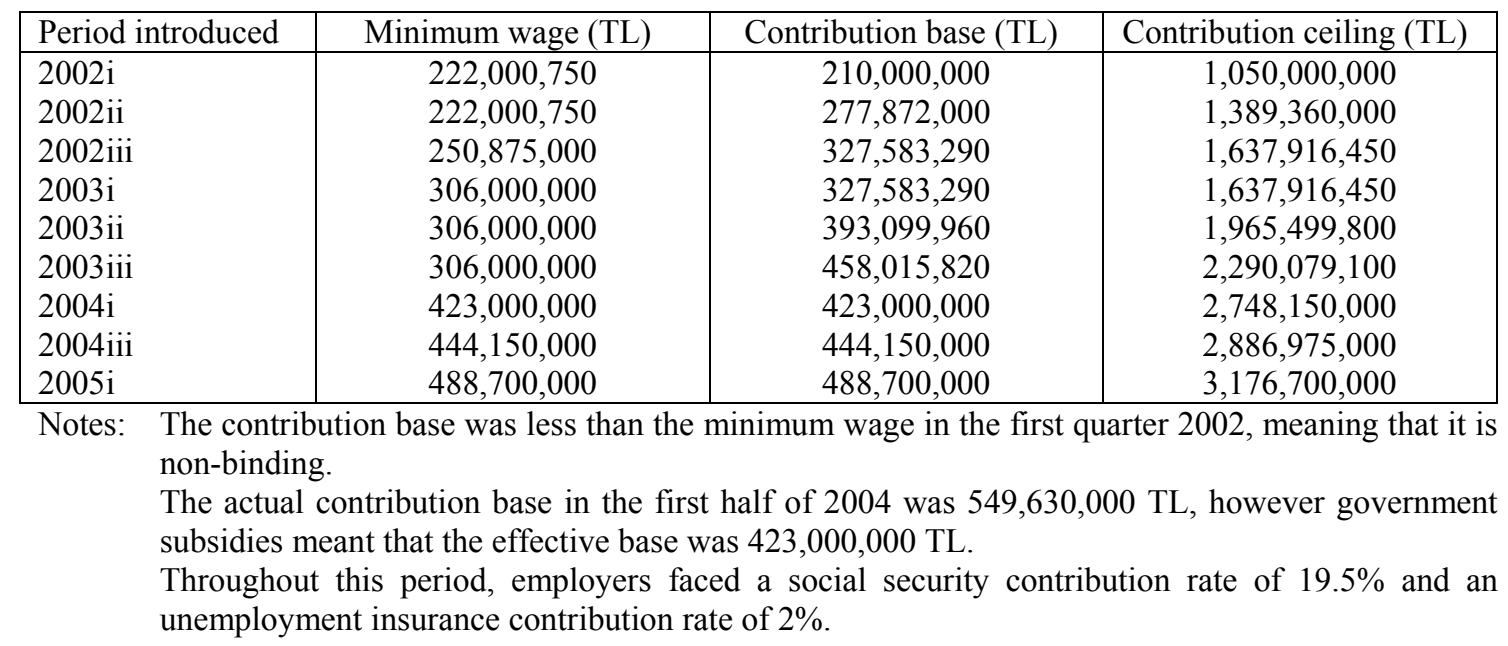

contribution rate for this was $19.5 \%$ and the employee contribution rate was $14 \%$. For the unemployment insurance fund, the employer contribution rate was $2 \%$ and the employee contribution rate was $1 \%$. However, there were minimum and maximum monthly contribution levels for the two funds. When the wage exceeded a contribution ceiling, both employers and employees contributed a fixed lira amount to the social security system. On the other hand, workers with wages below a contribution base level faced the standard contribution rate, however their employers paid an amount in excess of the usual contribution rate in order to cover the shortfall in the combined social security contributions of the two parties.

Both the contribution base and contribution ceiling changed regularly over time, as shown in Table 1. In most cases, these levels were increased in order to keep pace with inflation. A monthly minimum wage also exists. This was raised five times during the sample period, thus adding to total labour costs for employers of low-wage workers. Starting in July 2004, the contribution base and minimum wage were synchronised, meaning that employers never faced a contribution rate above $21.5 \%$. Employees also pay a stamp tax equal to $0.6 \%$ of their gross wage and an income tax, which is based on their income net of social security contributions. ${ }^{2}$ The income tax system is progressive, with $15 \%, 20 \%, 25 \%, 30 \%, 35 \%$ and $40 \%$ marginal tax rates, although the last of these

\footnotetext{
${ }^{2}$ A standard deduction was also applied to every person's gross income prior to 2004.
} 


\section{Figure 2}

Ratio of total labour cost to gross wage in selected quarters

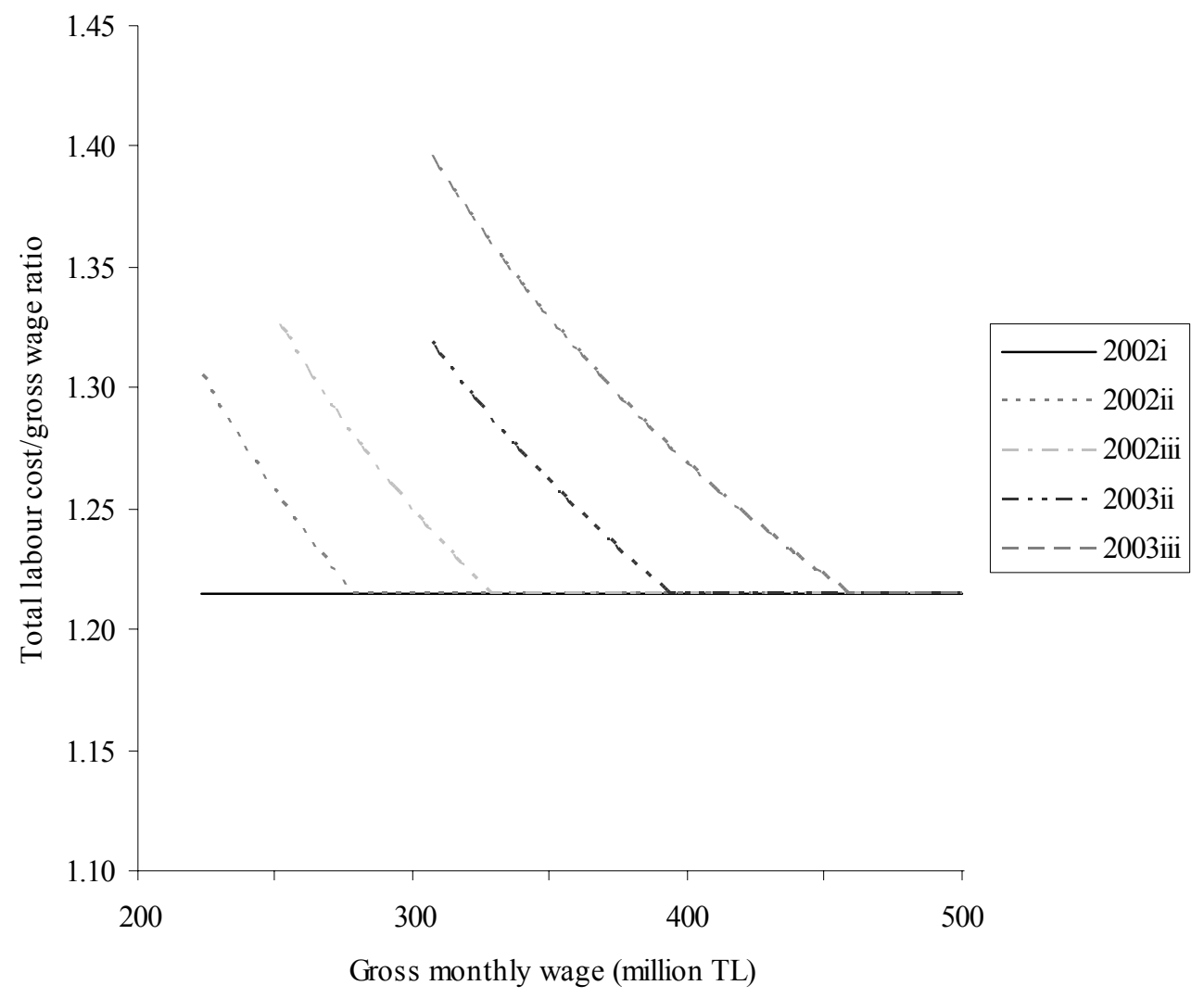

was eliminated in 2005. The income brackets corresponding to these were steadily increased between 2002 and 2005.

Figure 2 depicts the ratio of the total monthly labour cost faced by employers to the gross wage for those quarters in which the contribution base changed in 2002 and 2003 and for wage rates less than 500 million TL. After 2004, the ratio is always equal to 1.215 in this wage range because the contribution base is set equal to the minimum wage. The downward-sloping sections of the total labour cost curves before 2004 reflect the fact both that employers have to contribute more to the social security system as the wage falls and that this constitutes a larger fraction of the gross wage. This results in an effective tax rate that can be much higher than the standard $21.5 \%$ - up to $39.6 \%$ in the second half of 2003. In addition to the situation depicted for low wage earners, the total labour cost/wage ratio falls below 1.215 at wages above the contribution ceiling, since employer contributions are fixed in this region. These facts suggest that it may be 
Figure 3

Effects of increases in the minimum wage and contribution base

a. Increase in minimum wage

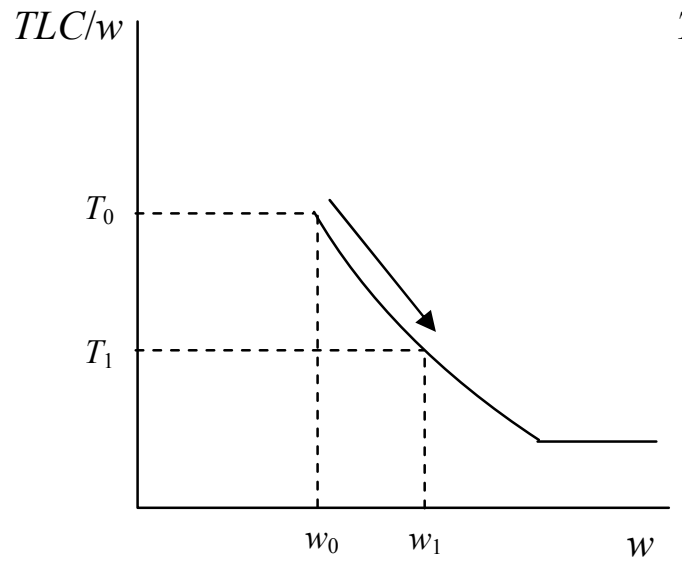

b. Increase in contribution base

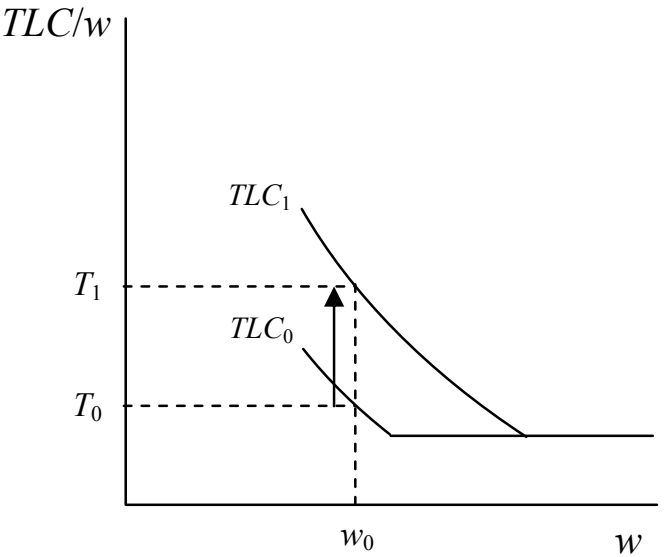

possible to construct two natural experiments. The employment effects of changes in the contribution base or minimum wage that influence the total labour cost ratio among lowwage workers can be analysed. Although not depicted in Figure 2, variation in the contribution ceiling can be used in a similar fashion to examine the effect of payroll taxes on the employment of high-wage workers.

Increases in the minimum wage and contribution base both lead to rises in the total cost of labour faced by employers, however these take different forms. The former involves a transfer of money from employers to their employees; the latter a transfer from employers to the government. The two cases are illustrated in Figure 3, which assumes that the minimum wage is less than the contribution base so that there is a downwardsloping portion of the total labour cost curve. Figure 3a depicts the case where the minimum wage is increased from $w_{0}$ to $w_{1}$. This is represented as a movement along the total labour cost curve. The total labour cost incurred by an employer of a minimum wage worker rises from $w_{0} T_{0}$ to $w_{1} T_{1}{ }^{3}$ In contrast, an increase in the contribution base is shown in Figure 3b. Here the total labour cost curve itself shifts upwards, from $T L C_{0}$ to $T L C_{1}$, and the employer of a worker earning a wage, $w_{0}$, less than the new contribution base, faces a rise in total labour cost from $w_{0} T_{0}$ to $w_{0} T_{1}$. Since even if both the minimum wage

${ }^{3} w_{1} T_{1}>w_{0} T_{0}$ because the slope of the total labour cost curve is always less than 1 in absolute value. 
and contribution base rise simultaneously (as in July 2002), the increase in labour costs can be decomposed into a movement along the total labour cost curve (due to the minimum wage) and a shift of the curve (due to the contribution base), separate treatment variables can be constructed for the two sources of cost increase.

\section{Data}

Quarterly data from the Household Labour Force Survey (HLFS) for 2002 to 2005 are analysed. ${ }^{4}$ In addition to basic demographic information, the survey collects information on whether a person is currently employed and, if so, whether his/her main job is registered with one of the three social security institutions. Workers who are registered with SSK or ES are considered to work in the formal sector and be subject to minimum wage and social security legislation, while employees who are unregistered are considered to be in the informal sector and not bound by this legislation. ${ }^{5}$ Self-employed workers (who are covered by BK) are excluded from the analysis.

A person's net income from this job in the previous month is also recorded. For people who reported working only part of the month, income was scaled up to reflect a full-month amount. Gross monthly income and total labour cost were calculated from this, using parameters from the income tax and social security systems for the relevant quarter under the assumption that each person earns the same amount in each month of the calendar year. Although the Turkish lira was redenominated in January 2005, all monetary values in this paper are expressed in old lira (TL). A small number of workers who earned a very low monthly income (less than 10 million TL in January 2002 lira) or a very high income (more than 10 billion TL) were excluded.

\footnotetext{
${ }^{4}$ Questions on a respondent's income have only been included in the HLFS since 2002. During 2002, the Turkish economy was recovering from the financial crisis, which may have disrupted the labour market in that year. However, the results in the next section are very similar if the sample period is restricted to 2003 2005.

${ }^{5}$ Kanbur (2010) discusses the various concepts of informal employment and classifies them into the cases where regulation is applicable but the firm is non-compliant, where regulation is non-applicable after the firm adjusts its activity and where regulation is non-applicable to the activity. Since all jobs should be registered for social security purposes in Turkey, here informal employment refers only to the first of these classifications; therefore it seems reasonable to assume that the firm will ignore minimum wage legislation too.
} 


\section{Figure 4}

Distribution of gross wages and the minimum wage across registered jobs, 2002-2005
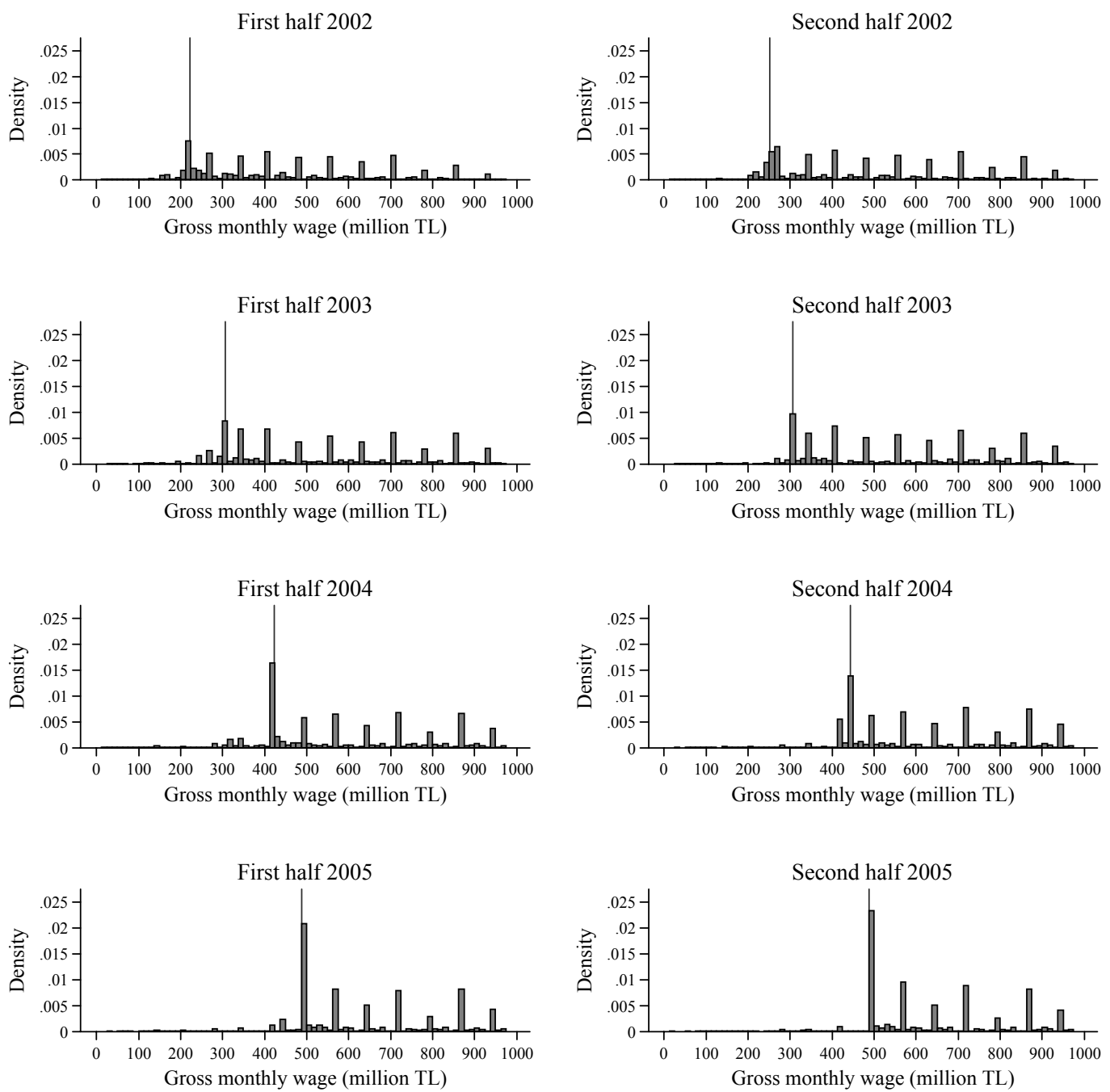

Notes: Vertical spike denotes prevailing minimum wage.

Only individuals with gross monthly wages less than or equal to 1 billion TL are included.

The gross wage distribution among those in the formal sector is depicted in Figure 4, along with the prevailing minimum wage. ${ }^{6}$ The histograms are restricted to those observations with gross wages between 0 and 1 billion TL. A low level of non-

\footnotetext{
${ }^{6}$ The wage distribution in the informal sector does not appear to be bound by the minimum wage, suggesting that Turkey does not display the so-called "lighthouse effect" seen in Latin America, whereby minimum wages influence wage setting in the unregulated sector (Maloney and Nuñez (2004)).
} 
Table 2

Wage distribution by quarter

\begin{tabular}{|l|c|c|c|c|}
\hline Quarter & $\begin{array}{c}\text { Wage less than } \\
\text { minimum wage }\end{array}$ & $\begin{array}{c}\text { Wage between } \\
\text { minimum wage and } \\
\text { contribution base }\end{array}$ & $\begin{array}{c}\text { Wage between } \\
\text { contribution base } \\
\text { and ceiling }\end{array}$ & $\begin{array}{c}\text { Wage above } \\
\text { contribution ceiling }\end{array}$ \\
\hline $2002 \mathrm{i}$ & $17.75 \%$ & - & $75.62 \%$ & $6.63 \%$ \\
$2002 \mathrm{ii}$ & $20.67 \%$ & $16.52 \%$ & $59.50 \%$ & $3.31 \%$ \\
$2002 \mathrm{iii}$ & $22.45 \%$ & $15.78 \%$ & $59.95 \%$ & $1.82 \%$ \\
$2002 \mathrm{iv}$ & $18.50 \%$ & $16.73 \%$ & $62.56 \%$ & $2.21 \%$ \\
$2003 \mathrm{i}$ & $25.50 \%$ & $3.28 \%$ & $68.52 \%$ & $2.70 \%$ \\
$2003 \mathrm{ii}$ & $20.20 \%$ & $15.62 \%$ & $61.89 \%$ & $2.28 \%$ \\
$2003 \mathrm{iii}$ & $15.82 \%$ & $27.41 \%$ & $54.52 \%$ & $2.24 \%$ \\
$2003 \mathrm{iv}$ & $14.74 \%$ & $25.62 \%$ & $57.01 \%$ & $2.63 \%$ \\
$2004 \mathrm{i}$ & $32.54 \%$ & - & $67.42 \%$ & $1.05 \%$ \\
$2004 \mathrm{ii}$ & $24.23 \%$ & - & $74.52 \%$ & $1.21 \%$ \\
$2004 \mathrm{iii}$ & $23.20 \%$ & - & $85.59 \%$ & $1.22 \%$ \\
$2004 \mathrm{iv}$ & $16.80 \%$ & - & $80.93 \%$ & $1.33 \%$ \\
$2005 \mathrm{i}$ & $17.73 \%$ & - & $84.99 \%$ & $1.16 \%$ \\
$2005 \mathrm{ii}$ & $13.85 \%$ & - & $85.49 \%$ & $1.68 \%$ \\
$2005 \mathrm{iii}$ & $12.83 \%$ & - & $86.37 \%$ & $1.73 \%$ \\
$2005 \mathrm{iv}$ & $11.90 \%$ & - & \\
\hline
\end{tabular}

compliance is observed, with few observations significantly below the minimum. The minimum wage did not appear to be a binding constraint during 2002 and 2003, however after a $38 \%$ increase in January 2004 it is seen to have a clear impact on the wage distribution. The large spike at the minimum wage suggests that many workers who were previously paid less than the new minimum wage are not laid off but rather are retained and paid a higher amount. This is similar to the pattern Card and Krueger (1995) found in the United States. ${ }^{7}$

Table 2 reveals how the observed wage distribution relates to the social security system, as discussed in the previous section. The majority of people earn a wage that lies between the contribution base and the contribution ceiling and hence have a constant employer contribution rate. A significant number of workers in registered jobs earn less than the minimum wage, although since many of these earn only slightly less than the minimum this does not necessarily indicate non-compliance, given that the gross wage is

\footnotetext{
${ }^{7}$ As Card and Krueger noted, this finding is at odds with a strict interpretation of the neoclassical model of labour supply and demand, in which workers should never be employed at a wage exceeding their marginal product of labour.
} 
calculated from the net wage and hence is subject to measurement error. Very few people earn a wage in excess of the contribution ceiling. For this reason, the analysis in the next section will focus on the natural experiment that arises from changes in the contribution base and minimum wage.

Households are sampled by the HLFS for two consecutive quarters, then exit for two quarters and return for two final quarters. Hence, households are observed in the same two quarters in adjacent years. Unfortunately, however, it was only possible to match households within each calendar year, meaning that the minimum wage and contribution base changes that took place in the first quarters of 2003, 2004 (when the contribution base actually fell) or 2005 could not be analysed. Furthermore, a combination of survey attrition and missing longitudinal identification variables means that some households only have one observation in a year and hence cannot be used in the panel analysis. ${ }^{8}$ To allow for the facts that the match rates change over time and that the survey was enlarged considerably in 2004, the HLFS sampling weights are adjusted so that the total weight of each quarter's observations is the same.

\section{Analysis}

The objective is to assess the impact of a change in the total labour cost associated with a person's job on his/her future likelihood of being employed. Following Currie and Fallick (1996) and Kramarz and Philippon (2001), this is done by constructing a treatment variable, reflecting the "intensity" of a policy change on each individual. The total labour cost of each worker is first calculated, based on his/her observed gross wage in a given period. The total labour cost that would be incurred by the employer $s$ periods in the future is then calculated, under the assumption that the worker remained employed at the initial period's wage and taking into account any changes in the social security contribution base or minimum wage. The treatment variable, $y$, is the difference between the two total labour cost values, expressed in billions of lira:

\footnotetext{
${ }^{8}$ Tunal1 (2009) examined attrition in the HLFS and found that household heads who are unemployed at the time of their initial interview are significantly more likely than average to exit the survey within three months. This is likely to introduce bias, although by focusing only on those people who are initially employed, this study should largely avoid this. Further confidence is taken from the fact that the matched and non-matched households are very similar in terms of observable characteristics, as can verified by comparing Table A1 with Table 3.
} 


$$
y_{i t}=\frac{T L C_{t+s}\left(w_{i t}\right)-T L C_{t}\left(w_{i t}\right)}{1,000,000,000},
$$

where $T L C_{t}(\cdot)$ is a function returning the total labour cost in period $t$ for any gross wage. Hence, $y$ reflects a counterfactual change in labour costs that would be faced by a firm if it chose to continue hiring a worker at the same wage. This will be equal to zero for workers whose cost does not change from between periods and, in order to focus on lowwage workers, it is also set equal to zero for workers who are affected by increases in the contribution ceiling. The larger a worker's value of $y$, the more changes in policies governing payroll taxes or the minimum wage have influenced his/her labour cost. Currie and Fallick referred to $y$ as a "wage gap", although here it is more properly termed a "total labour cost gap". As discussed in Section 2, the total labour cost gap can be decomposed into the portion due to changes in the minimum wage, $y^{M W}$, and the portion due to changes in the contribution base, $y^{C B}$, so that $y_{i t}=y_{i t}^{M W}+y_{i t}^{C B}$. Since the contribution base was set equal to the minimum wage in 2004, $y_{i t}^{C B}=0$ after this point.

In the panel dataset discussed in the previous section, households are observed twice in a given year: in quarters $t$ and $t-s$, where $s=1$ or $s=3$. Similar to Currie and Fallick, the probability that individuals who were employed in quarter $t-s$ were still employed in quarter $t$ is considered. The sample is restricted to those aged between 16 and 64 and the following employment equation is estimated with ordinary least squares, using the adjusted survey weights discussed earlier: ${ }^{9}$

$$
E_{i t}=\alpha y_{i(t-s)}+\mathbf{X}_{i(t-s)} \boldsymbol{\beta}+\lambda_{t}+\varepsilon_{i t} \text {. }
$$

The dependent variable here, $E_{i t}$, is a dummy variable for whether person $i$ is employed in quarter $t$, given that $E_{i(t-s)}=1$. Quarter dummies, $\lambda$, are included to control for macroeconomic factors and $\mathbf{X}$ includes age, sex, urban status, marital status, education level, whether the person was employed in an unregistered job in $t-s$ and a dummy for whether there was a nine month gap between interviews rather than a three month gap (i.e. whether $s=3$ ).

\footnotetext{
${ }^{9}$ A linear probability model is used for simplicity and to maintain comparability with Currie and Fallick (1996), however the results are almost identical when a probit specification is used.
} 
Table 3

Means for the regression samples

\begin{tabular}{|l|c|c|c|}
\hline Variable & Total sample & Bound workers & Unbound workers \\
\hline Age & 33.794 & 31.081 & 34.118 \\
Male & 0.804 & 0.770 & 0.808 \\
Urban & 0.779 & 0.794 & 0.778 \\
Married & 0.747 & 0.699 & 0.753 \\
Primary education & 0.429 & 0.538 & 0.416 \\
Secondary education & 0.390 & 0.410 & 0.388 \\
Tertiary education & 0.166 & 0.043 & 0.181 \\
Previously employed in registered job & 0.692 & 1 & 0.655 \\
Total cost gap & 0.002 & 0.018 & 0 \\
Minimum wage cost gap & 0.001 & 0.005 & 0 \\
Contribution base cost gap & 0.001 & 0.013 & 0 \\
Previous gross monthly income & $708,791,000 \mathrm{TL}$ & $317,015,028 \mathrm{TL}$ & $755,584,059 \mathrm{TL}$ \\
Employed & 0.803 & 0.795 & 0.804 \\
\hline Number of observations & 61,723 & 3,793 & 57,930 \\
\hline
\end{tabular}

Notes: The samples are restricted to those aged 16-64 who were employed in the previous quarter surveyed and use the HLFS sampling weights, adjusted so that the total weight in each quarter is the same.

The treatment group here consists of those workers who were registered with SSK in $t-s$ at a wage between the old contribution base and the new minimum wage (and hence experienced an increase in total labour costs). In periods where neither the contribution base nor the minimum wage changes, this group is empty. The comparison group consists of three subgroups: all workers who earned more than the new minimum wage in $t-s$; workers who were either registered with ES or not registered with any social security institution in $t-s$ and earned a wage between the old contribution base and the new minimum; and wage earners who were not registered in $t-s$ and earned less than the old minimum. ${ }^{10}$ Hence, low-wage private sector workers will be compared with higherearning private sector workers and workers in the public and informal sectors.

Means for key demographic and employment variables for the regression sample are presented in the first column of Table 3. Relative to the working-age population, the sample is dominated by men, the more educated, those who are married and those living in cities. In the second and third columns of the table, means for those who are bound by changes in the total cost schedule (so that $y_{i t}>0$ ) and those who are not bound (so that

\footnotetext{
${ }^{10}$ A small number of people $(1.9 \%$ of the sample) were dropped from the dataset because they reported a wage that was less than the $95 \%$ of the prevailing minimum wage but claimed to be registered with SSK or ES. Those within $5 \%$ of the minimum are included because of the measurement error problem discussed earlier.
} 
Table 4

Estimates of employment equations

\begin{tabular}{|c|c|c|c|c|}
\hline \multirow[t]{2}{*}{ Variable } & \multicolumn{2}{|c|}{ Employed } & \multicolumn{2}{|c|}{ Employed in same job } \\
\hline & (i) & (ii) & (iii) & (iv) \\
\hline Total cost gap & $\begin{array}{c}-1.792 * * * \\
(0.230)\end{array}$ & - & $\begin{array}{c}-2.900 * * * \\
(0.248)\end{array}$ & - \\
\hline Minimum wage cost gap & (- & $\begin{array}{c}-1.490 * * * \\
(0.426)\end{array}$ & $(-2,4)$ & $\begin{array}{c}-2.425 * * * \\
(0.460)\end{array}$ \\
\hline Contribution base cost gap & - & $\begin{array}{c}-1.967 * * * \\
(0.310)\end{array}$ & - & $\begin{array}{c}-3.176 * * * \\
(0.335)\end{array}$ \\
\hline Age & $\begin{array}{c}-0.002 * * * \\
(0.000)\end{array}$ & $\begin{array}{c}-0.002 * * * \\
(0.000)\end{array}$ & $\begin{array}{l}-0.000 \\
(0.000)\end{array}$ & $\begin{array}{l}-0.000 \\
(0.000)\end{array}$ \\
\hline Male & $\begin{array}{c}0.110 * * * \\
(0.004)\end{array}$ & $\begin{array}{c}0.110 * * * \\
(0.004)\end{array}$ & $\begin{array}{c}0.092 * * * \\
(0.004)\end{array}$ & $\begin{array}{c}0.092 * * * \\
(0.004)\end{array}$ \\
\hline Urban & $\begin{array}{c}0.022 * * * \\
(0.004)\end{array}$ & $\begin{array}{c}0.022 * * * \\
(0.004)\end{array}$ & $\begin{array}{c}0.005 \\
(0.004)\end{array}$ & $\begin{array}{c}0.005 \\
(0.004)\end{array}$ \\
\hline Married & $\begin{array}{c}0.020 * * * \\
(0.004)\end{array}$ & $\begin{array}{c}0.020 * * * \\
(0.004)\end{array}$ & $\begin{array}{c}0.024 * * * \\
(0.005)\end{array}$ & $\begin{array}{c}0.024 * * * \\
(0.005)\end{array}$ \\
\hline Secondary education & $\begin{array}{l}0.052 * * * \\
(0.004)\end{array}$ & $\begin{array}{c}0.052 * * * \\
(0.004)\end{array}$ & $\begin{array}{l}0.060 * * * \\
(0.004)\end{array}$ & $\begin{array}{c}0.060^{* * *} \\
(0.004)\end{array}$ \\
\hline Tertiary education & $\begin{array}{c}0.125 * * * \\
(0.005)\end{array}$ & $\begin{array}{c}0.125 * * * \\
(0.005)\end{array}$ & $\begin{array}{c}0.140 * * * \\
(0.005)\end{array}$ & $\begin{array}{c}0.140 * * * \\
(0.005)\end{array}$ \\
\hline $\begin{array}{l}\text { Three quarters since previous } \\
\text { observation }\end{array}$ & $\begin{array}{c}-0.052 * * * \\
(0.006)\end{array}$ & $\begin{array}{c}-0.052 * * * \\
(0.006)\end{array}$ & $\begin{array}{c}-0.045 * * * \\
(0.006)\end{array}$ & $\begin{array}{c}-0.045 * * * \\
(0.006)\end{array}$ \\
\hline Previously in registered job & $\begin{array}{c}0.202 * * * \\
(0.004)\end{array}$ & $\begin{array}{c}0.202 * * * \\
(0.004)\end{array}$ & $\begin{array}{c}0.254 * * * \\
(0.004)\end{array}$ & $\begin{array}{c}0.254 * * * \\
(0.004)\end{array}$ \\
\hline R-squared & 0.107 & 0.107 & 0.123 & 0.123 \\
\hline Number of observations & 61,723 & 61,723 & 61,641 & 61,641 \\
\hline
\end{tabular}

Notes: All regressions include dummy variables for each quarter (12 variables).

Standard errors are presented in parentheses. $*, * *$ and $* * *$ denote significance at the $10 \%, 5 \%$ and $1 \%$ level, respectively.

Regressions use HLFS sampling weights, adjusted so that the total weight in each quarter is the same.

$\left.y_{i t}=0\right)$ are reported. Not surprisingly, those who are affected by the policy changes are younger and less likely to be married than the comparison group.

The first column of Table 4 presents the results of estimating Equation 2. There is significant evidence that an increase in total labour cost brought about by the minimum wage rise reduces a person's likelihood of remaining employed: a 1 million TL (approximately equal to US \$0.70) increase in the total labour cost gap reduces the probability of being employed by $0.18 \%$. At the mean, this implies that a $1 \%$ increase in the total labour cost of a treated worker yields a $0.53 \%$ fall in the probability of $\mathrm{him} / \mathrm{her}$ remaining employed a quarter later. The other control variables have the expected signs: being younger, male, married and more educated and living in an urban area all increase the likelihood of employment, as does being in a registered job in the previous quarter. 
As discussed in Section 2, the total labour cost gap can be decomposed into a minimum wage cost gap and a contribution base cost gap. In order to find the separate employment effects of changes in each, the second column of Table 4 reports estimates of the following equation:

$$
E_{i t}=\alpha^{M W} y_{i(t-s)}^{M W}+\alpha^{C B} y_{j(t-s)}^{C B}+\mathbf{X}_{i(t-s)} \boldsymbol{\beta}+\lambda_{t}+\varepsilon_{i t} .
$$

A one million TL increase in labour costs resulting from an increase in the contribution base is found to lead to a $0.20 \%$ fall in the probability of remaining employed, whereas the same increase in costs resulting from an increase in the minimum wage results in only a $0.15 \%$ decrease in the probability of employment. Although this difference is not statistically significant, it runs counter to the predictions of the basic textbook model of labour demand, in which the disemployment effects that result from the imposition of a payroll tax should never exceed those resulting from the imposition of a minimum wage which increases the equilibrium wage by an equal amount, because in the former case the employer may be able to pass on some of the tax to the worker in the form of lower wages. In contrast, the results here indicate that employers are less likely to shed workers if an increase in labour costs results in a transfer to employees rather than the government.

The estimated coefficients on Currie and Fallick's (1996) wage gap imply an employment elasticity with respect to the minimum wage of -0.23 when OLS is used. This is remarkably close to the -0.25 figure that is obtained from the regression in the second column of Table 4 (using the fact that bound workers experienced an average $3.0 \%$ increase in the minimum wage). Currie and Fallick's elasticity falls slightly to -0.20 when they switch to fixed effects estimation, suggesting that the coefficients in Table 4 may overstate the true values. Since the HLFS data allow only one observation for each person, it is not possible to include individual fixed effects here, however including a dummy for registered job in the previous quarter controls for differences in employment stability between workers in the informal and formal sectors. Furthermore, adding a worker's wage in the previous period to the set of regressors to control for differences in employment stability by wage level has almost no effect on the results in Table 4.

According to the textbook model, the employment effect of a (binding) minimum wage should be determined by the shape of labour demand. Krishna et al. (2002) 
previously estimated labour demand elasticities in Turkey, using data collected from formal sector enterprises in manufacturing industries for 1983-1986. They found a pooled labour demand elasticity of about -0.55 , with 6 of the 10 industries having elasticities of between -0.15 and -0.75 . When Equation 3 was modified to reflect the probability of those initially employed in manufacturing jobs remaining in the manufacturing industry the next period, the elasticity associated with the minimum wage cost gap was found to be -0.15 . This is actually an upper bound on the elasticity (since manufacturing employers might respond to an increase in costs by substituting workers from outside the industry for current workers), again suggesting that the minimum wage leads to a smaller fall in employment than would be predicted by a movement along the labour demand curve.

The HLFS asks respondents how long they had been employed in their current job; therefore, it is possible to determine whether a person had left a given job since the previous quarter. The last two columns of Table 4 estimate Equations 2 and 3 again, where the dependent variable now indicates whether a person is employed in the same job in quarter $t$ as in quarter $t-s$. Not surprisingly, the effects of all treatment variables are larger than in the previous columns. A one million TL increase in total labour costs results in a $0.29 \%$ increase in the probability of workers leaving their current jobs, but only a $0.18 \%$ increase in the probability of them leaving the wage and salary sector altogether, because many find other jobs.

Card and Krueger (1995) criticised Linneman's (1982) decision to compare minimum wage workers with those earning more than the minimum wage, noting that the former group is likely to have more unstable employment histories than the latter, even in years in which the minimum wage did not change. One way to circumvent this criticism is to add a person's gross monthly income in the previous period to the set of controls in Equation 3. Although unreported, this is found to reduce the magnitude of the coefficients on the cost gap variables only slightly.

Card and Krueger's preferred approach is to restrict the sample of workers to those who initially have low wage rates, thereby creating a more homogenous comparison group. Table 5 reports estimates of Equations 2 and 3, using only one of the three comparison groups in each column (except the first column, which repeats the baseline 
Table 5

Estimates of employment equations using different comparison groups

\begin{tabular}{|c|c|c|c|c|}
\hline \multirow[t]{2}{*}{ Variable } & \multicolumn{4}{|c|}{ Choice of comparison group } \\
\hline & $\begin{array}{c}\text { (i) } \\
\text { All groups }\end{array}$ & $\begin{array}{c}\text { (ii) } \\
\text { High-wage workers }\end{array}$ & $\begin{array}{c}\text { (iii) } \\
\text { Low-wage workers }\end{array}$ & $\begin{array}{c}\text { (iv) } \\
\text { Uncovered workers }\end{array}$ \\
\hline \multicolumn{5}{|c|}{ Single treatment variable } \\
\hline Total cost gap & $\begin{array}{c}-1.792 * * * \\
(0.230)\end{array}$ & $\begin{array}{c}-1.486^{* * *} \\
(0.217)\end{array}$ & $\begin{array}{c}-1.173 * * \\
(0.481)\end{array}$ & $\begin{array}{c}-1.582 * * \\
(0.632)\end{array}$ \\
\hline \multicolumn{5}{|c|}{ Separate treatment variables } \\
\hline $\begin{array}{l}\text { Minimum wage } \\
\text { cost gap } \\
\text { Contribution base } \\
\text { cost gap }\end{array}$ & $\begin{array}{c}-1.490 * * * \\
(0.426) \\
-1.967 * * * \\
(0.310) \\
\end{array}$ & $\begin{array}{c}-1.623 * * * \\
(0.400) \\
-1.405 * * * \\
(0.294) \\
\end{array}$ & $\begin{array}{c}-0.173 \\
(0.687) \\
-1.932 * * * \\
(0.609) \\
\end{array}$ & $\begin{array}{c}-0.475 \\
(0.851) \\
-2.683 * * * \\
(0.851) \\
\end{array}$ \\
\hline $\begin{array}{l}\text { Number of } \\
\text { observations }\end{array}$ & 61,723 & 50,952 & 12,524 & 5,833 \\
\hline
\end{tabular}

Notes: All regressions also include age and dummies for sex, urban status, marital status, education level ( 2 variables), whether it is three quarters since the previous observation, whether previously employed in a registered job and quarter (12 variables).

Standard errors are presented in parentheses. $*, * *$ and $* * *$ denote significance at the $10 \%, 5 \%$ and $1 \%$ level, respectively.

Regressions use HLFS sampling weights, adjusted so that the total weight in each quarter is the same.

results from Table 4). In the second column, the workers who are bound by the policy changes are compared with those who earn higher wages. As Card and Krueger predicted, the minimum wage effect is larger in this regression, although interestingly the contribution base effect is smaller. ${ }^{11}$ In the third column, the comparison group is comprised of those who earn less than the bound group. In this case, the minimum wage effect is insignificant but the contribution base effect is similar to the baseline case. In the final column, the bound group is compared with workers whose earnings are in the same range but who are either not registered for social security purposes or registered with ES. This is comparable to the approach taken by Ashenfelter and Card (1981). The contribution base effect is larger than in the baseline case although, once again, the minimum wage effect is insignificant. In both the third and fourth columns, the contribution base effect is significantly larger than the minimum wage effect at the $10 \%$ level.

Focusing only on changes in employment status precludes the possibility that some of

\footnotetext{
${ }^{11}$ The coefficients are not significantly different from each other. If only workers earning less than 500 million TL in the previous quarter are included in the comparison group, the minimum wage gap coefficient is slightly larger than the contribution base gap coefficient, however once again the difference is not significant.
} 
Table 6

Estimates of equations for changes in the number of days and weekly hours worked

\begin{tabular}{|c|c|c|c|c|}
\hline \multirow[t]{2}{*}{ Variables } & \multicolumn{2}{|c|}{ Employed } & \multicolumn{2}{|c|}{ Employed in same job } \\
\hline & $\begin{array}{c}\text { (i) } \\
\text { Change in days }\end{array}$ & $\begin{array}{c}\text { (ii) } \\
\text { Change in hours }\end{array}$ & $\begin{array}{c}\text { (iii) } \\
\text { Change in days }\end{array}$ & $\begin{array}{c}\text { (iv) } \\
\text { Change in hours }\end{array}$ \\
\hline \multicolumn{5}{|c|}{ Single treatment variable } \\
\hline Total cost gap & $\begin{array}{c}-28.822 * * * \\
(3.146)\end{array}$ & $\begin{array}{c}-43.914 * * * \\
(8.175)\end{array}$ & $\begin{array}{c}-18.758 * * * \\
(2.553) \\
\end{array}$ & $\begin{array}{c}-50.867 * * * \\
(8.329) \\
\end{array}$ \\
\hline \multicolumn{5}{|c|}{ Separate treatment variables } \\
\hline $\begin{array}{l}\text { Minimum wage } \\
\text { cost gap } \\
\text { Contribution base } \\
\text { cost gap }\end{array}$ & $\begin{array}{c}-18.053 * * * \\
(5.764) \\
-34.998 * * * \\
(4.191)\end{array}$ & $\begin{array}{c}-21.403 \\
(14.996) \\
-56.795 * * * \\
(10.889) \\
\end{array}$ & $\begin{array}{c}-13.875^{* * *} \\
(4.706) \\
-21.476 * * * \\
(3.370) \\
\end{array}$ & $\begin{array}{c}-34.878 * * \\
(15.372) \\
-59.746 * * * \\
(10.993) \\
\end{array}$ \\
\hline $\begin{array}{l}\text { Number of } \\
\text { observations }\end{array}$ & 50,432 & 50,287 & 46,922 & 46,857 \\
\hline
\end{tabular}

Notes: All regressions also include age and dummies for sex, urban status, marital status, education level ( 2 variables), whether it is three quarters since the previous observation, whether previously employed in a registered job and quarter (12 variables).

Standard errors are presented in parentheses. $*, * *$ and $* * *$ denote significance at the $10 \%, 5 \%$ and $1 \%$ level, respectively.

Regressions use HLFS sampling weights, adjusted so that the total weight in each quarter is the same.

the adjustment in employment levels takes place in terms of the amount of time worked by each worker rather than in the number of workers. To examine this so-called intensive margin, in Table 6 the regressions from Table 4 are repeated, but including only those who remain employed in current quarter (in the first two columns) or employed in the same job (in the last two columns). In the first column, the change from the previous quarter in the number of days worked in the previous month is used as a dependent variable. A one million TL increase in the minimum wage cost gap leads to a 0.018 decrease in the number of days worked per month but an equal-sized increase in the contribution base cost gap results in a 0.035 fall in days worked. The contribution base is also found to result in a larger fall in the number of hours worked per week than the minimum wage, as seen in the second column of the table. In both the days and hours regressions, the minimum wage and contribution base effects are significantly different from each other, although both are modest in magnitude. Similar patterns are found when the regression is restricted to those who remain in the job they had in the previous quarter, as reported in the third and fourth columns of Table 6.

Minimum wages have been found to cause only modest reductions in employment levels in other developing countries, as noted by Neumark and Wascher (2007) in their 
survey of the literature. The most common explanations for this are the presence of monopsonies or the fact that labour demand is very elastic at low wage rates. In either case, any given increase in the cost of labour should lead to the same change in employment, regardless of the reason behind it. ${ }^{12}$ This is contradicted by the evidence presented above, which indicates that changes in labour costs have more effect on employment probabilities when they are caused by changes in payroll taxes rather than by changes in minimum wages. The obvious difference between these two types of policy is that a minimum wage rise results in an increase in the take-home pay of the worker, whereas an increase in payroll taxes leaves the worker's pay unchanged. If workers respond to wage increases by putting more effort into their work or by reducing the probability of quitting their job, then employers will actually experience rises in labour productivity as a result of a minimum wage rise, but not from an equal-sized increase in payroll taxes. As shown by Rebitzer and Taylor (1995), they will then be less eager to cut jobs under the former policy than under the latter. ${ }^{13}$

This efficiency wage argument is particularly relevant to Turkey, where the loss of a job in the formal sector often forces workers to find employment in the informal sector, at a much lower wage rate. ${ }^{14}$ Since these jobs are unaffected by social security taxes or the minimum wage, they are assumed to pay a worker his/her marginal product. Formal sector workers who do not raise their effort levels (or reduce their probability of turnover) in response to a rise in their wage rates have the option of switching to the informal sector and continuing to earn their old wage in return for a lower effort level.

Certain demographic groups are much more likely to work in the formal sector than others. For example, $83 \%$ of workers with a secondary education work in the formal sector, while only $59 \%$ of primary-educated workers do. For groups with less recourse to

\footnotetext{
${ }^{12}$ If anything, a payroll tax increase might have a smaller effect if firms are able to offset the tax by lowering wages. This can be examined using the HLFS data on workers who remain employed between quarters. However, the results from such an analysis were found to be very sensitive to the exclusion of implausibly large wage changes, something that was also noted by Currie and Fallick (1996).

${ }^{13}$ Georgiadis (2008) found support for the efficiency wage argument, by analysing a natural experiment arising from the national minimum wage in the United Kingdom. Although Georgiadis's paper remedies some of the limitations of previous studies of efficiency wages, it shares the weakness of not having a counterfactual measure of employment when wages rise but worker incentives are not present.

${ }^{14}$ Controlling for other characteristics, workers in jobs registered with SSK were found to earn $36 \%$ more after tax than unregistered workers.
} 
Table 7

Estimates of employment equations for different subgroups

\begin{tabular}{|c|c|c|c|c|}
\hline \multirow[t]{2}{*}{ Subgroup } & \multicolumn{2}{|c|}{$\begin{array}{c}\text { (i) } \\
\text { Employed }\end{array}$} & \multicolumn{2}{|c|}{$\begin{array}{l}\text { (ii) } \\
\text { Employed in same job }\end{array}$} \\
\hline & $\begin{array}{c}\text { Minimum wage } \\
\text { cost gap coefficient }\end{array}$ & $\begin{array}{c}\text { Contribution base } \\
\text { cost gap coefficient }\end{array}$ & $\begin{array}{c}\text { Minimum wage } \\
\text { cost gap coefficient }\end{array}$ & $\begin{array}{l}\text { Contribution base } \\
\text { cost gap coefficient }\end{array}$ \\
\hline Women & $\begin{array}{l}-0.777 \\
(0.900)\end{array}$ & $\begin{array}{l}-0.888 \\
(0.693)\end{array}$ & $\begin{array}{l}-1.169 \\
(0.935)\end{array}$ & $\begin{array}{c}-1.760 * * \\
(0.720)\end{array}$ \\
\hline Men & $\begin{array}{c}-1.432 * * * \\
(0.482) \\
\end{array}$ & $\begin{array}{c}-2.432 * * * \\
(0.344) \\
\end{array}$ & $\begin{array}{c}-2.590 * * * \\
(0.527) \\
\end{array}$ & $\begin{array}{c}-3.644 * * * \\
(0.377) \\
\end{array}$ \\
\hline Rural & $\begin{array}{c}-2.261 * * \\
(0.969)\end{array}$ & $\begin{array}{c}-2.524 * * * \\
(0.772)\end{array}$ & $\begin{array}{c}-2.953 * * * \\
(1.019)\end{array}$ & $\begin{array}{c}-3.400 * * * \\
(0.812)\end{array}$ \\
\hline Urban & $\begin{array}{c}-1.245^{* * * *} \\
(0.476) \\
\end{array}$ & $\begin{array}{c}-1.865^{* * * *} \\
(0.336) \\
\end{array}$ & $\begin{array}{c}-2.267 * * * \\
(0.518) \\
\end{array}$ & $\begin{array}{c}-3.161 * * * \\
(0.366) \\
\end{array}$ \\
\hline $\begin{array}{l}\text { Aged 16-29 } \\
\text { Aged 30-64 }\end{array}$ & $\begin{array}{c}-1.787 * * * \\
(0.669) \\
-0.442 \\
(0.566) \\
\end{array}$ & $\begin{array}{c}-2.215 * * * \\
(0.497) \\
-1.027 * * \\
(0.407) \\
\end{array}$ & $\begin{array}{c}-2.826 * * * \\
(0.740) \\
-1.222 * * \\
(0.600) \\
\end{array}$ & $\begin{array}{c}-3.045 * * * \\
(0.550) \\
-2.693 * * * \\
(0.432) \\
\end{array}$ \\
\hline Primary education & $\begin{array}{l}-0.489 \\
(0.676)\end{array}$ & $\begin{array}{c}0.079 \\
(0.489)\end{array}$ & $\begin{array}{c}-1.430 * * \\
(0.724)\end{array}$ & $\begin{array}{c}-1.425 * * * \\
(0.524)\end{array}$ \\
\hline Secondary education & $\begin{array}{l}-1.699 * * * \\
(0.614)\end{array}$ & $\begin{array}{c}-2.603 * * * \\
(0.456)\end{array}$ & $\begin{array}{c}-2.309 * * * \\
(0.669)\end{array}$ & $\begin{array}{c}-3.467 * * * \\
(0.497)\end{array}$ \\
\hline Tertiary education & $\begin{array}{c}-3.488 * * \\
(1.424)\end{array}$ & $\begin{array}{l}-5.628 * * * \\
(0.949)\end{array}$ & $\begin{array}{c}-6.930 * * * \\
(1.611) \\
\end{array}$ & $\begin{array}{c}-6.152 * * * \\
(1.073) \\
\end{array}$ \\
\hline
\end{tabular}

Notes: All regressions also include age and dummies for sex, urban status, marital status, education level ( 2 variables), whether it is three quarters since the previous observation, whether previously employed in a registered job and quarter (12 variables).

Standard errors are presented in parentheses. ${ }^{*}, * *$ and $* * *$ denote significance at the $10 \%, 5 \%$ and $1 \%$ level, respectively.

Regressions use HLFS sampling weights, adjusted so that the total weight in each quarter is the same.

the informal sector, the only alternative to minimum wage employment is likely to be unemployment. Assuming that the unemployment benefit is lower than any informal sector wage, it might be expected that changes in the minimum wage would have larger disemployment effects on these workers. To examine this, Equation 3 is estimated separately for each sex, urban status, age and education group. Table 7 indicates that the contribution base effect continues to dominate the minimum wage effect in almost all cases. Men are found to be more likely to exit employment in response to a given increase in labour costs than women. This is in contrast to Ashenfelter and Card (1981), who found that women were affected more by minimum wage increases than men, although it is consistent with Wellington (1991). Rural-dwellers are affected slightly more by rises in labour costs (especially due to the minimum wage) than those living in urban areas. People aged under 30 have higher disemployment probabilities than older 
workers, however, somewhat surprisingly, people with secondary or tertiary educations are more likely to lose their jobs in response to labour cost increases than less-educated workers. This is likely to be due to the fact that those with more education tend to be younger and, hence, more vulnerable to unemployment than older workers (see Economic Research Forum (2005)).

Since changes in the contribution base measures pure changes in labour demand and changes in the minimum wage confound this effect with the productivity responses of workers, the difference in the coefficients on the minimum wage cost gap and the contribution base cost gap can be interpreted as an "efficiency wage effect". When the probability of leaving a particular job is used as a dependent variable in the last column of Table 4, the efficiency wage effect is found to increase the probability of remaining employed by $0.075 \%$ in response to a 1 million TL labour cost increase. In Table 7 , the largest efficiency wage effects found are for urban-dwellers, those aged 30-64 and those with a secondary education. These groups also have significantly lower fractions of informal sector jobs than the rest of the workforce. The one exception to the pattern is that men have a higher efficiency wage effect than women, despite having around the same fraction of informal sector jobs. This may be because men are more likely to be the primary earners within households and will therefore consider the prospect of a wage cut as a stronger incentive to increase productivity. Since workers who change jobs are likely to find work in the informal sector where possible, the efficiency wage effects should be more similar across groups of workers when the probability of being employed in any job is analysed. Again, this is found for all cases except men and women, as seen in the first column of the table.

If efficiency wages explain the lack of adjustment in employment to changes in minimum wages, workers might be expected to reduce hours spent on additional jobs in response to a minimum wage rise, as they devote more effort to their main job. The HLFS also asks questions on a person's usual weekly hours on any secondary job, including unpaid family work. Table A2 presents the results when the change in this variable is regressed on the treatment variables. Unfortunately, only around $2 \%$ of workers report having a secondary job in each quarter. Nevertheless, the minimum wage cost gap has a significant negative effect on hours worked on the secondary job, even 
though it has little effect on hours worked on the main job. This is consistent with a worker cutting back on other labour market activities in order to devote more effort to his/her main job after the wage on that job rises. The same result is found if unpaid work is excluded. The contribution base cost gap has no effect on hours worked on the secondary job.

Finally, the analysis was repeated focusing on workers in the upper end of the wage distribution, where changes in the contribution ceiling between 2002 and 2005 gave rise to variation in total labour costs. A contribution ceiling cost gap variable is constructed as defined in Equation 1, except now only workers who are registered with SSK and have wages greater the contribution ceiling in the previous quarter have positive values; the remainder have a contribution ceiling cost gap equal to zero. To ensure a more homogeneous comparison group, the sample was also restricted those with a gross wage greater than 1 billion TL. The results of these regressions are presented in Table A3. As expected, the contribution ceiling cost gap variable has a significant negative effect on both the probability of exiting employment and the probability of exiting one's current job, although the magnitude of this effect is smaller when the high-wage comparison group is used. The contribution ceiling effect is also smaller than the minimum wage and contribution base effects estimated among low-wage workers earlier.

\section{Conclusion}

This paper has examined the effects the minimum wage and the level of social security taxes paid by firms in Turkey have on the employment levels. Variation over time and among low-wage workers in the ratio of total labour costs to the gross wage gives rise to a natural experiment. Using a longitudinal dataset constructed from the Turkish Household Labour Force Survey for 2002-2005, estimates were obtained indicating that a one million TL (or US \$0.70) increase in a worker's labour costs arising from a minimum wage rise results in a $0.15 \%$ decrease in the probability of him $/$ her remaining employed in the following quarter, whereas a one million TL increase in costs resulting from an increase in social security contributions results in a $0.20 \%$ fall in employment probability. The difference between the two effects is even larger when only low-wage workers are used as a comparison group. Certain demographic groups, 
including men, rural-dwellers and those under 30 , are found to be more vulnerable to policy changes than others. The results indicate that employers are less likely to dismiss workers in response to a given increase in labour costs when the increase results in higher wages for their workers rather than in a transfer payment to the government, possibly because workers are likely to put more in more effort in the former case.

\section{References}

Ashenfelter, O. and Card, D. (1981). Using longitudinal data to estimate the employment effects of the minimum wage. Discussion Paper No. 98, London School of Economics.

Betcherman, G., Daysal, N.M. and Páges, C. (2010). Do employment subsidies work? Evidence from regionally targeted subsidies in Turkey. Labour Economics, forthcoming.

Card, D. and Krueger, A.B. (1995). Myth and measurement: The new economics of the minimum wage. Princeton, NJ: Princeton University Press.

Currie, J. and Fallick, B.C. (1996). The minimum wage and the employment of youth: Evidence from the NLSY. Journal of Human Resources, 31, 404-428.

Economic Research Forum (2005). Turkey country profile: The road ahead for Turkey. Cairo: Economic Research Forum.

Georgiadis, A. (2008). Efficiency wages and the economic effects of the minimum wage: Evidence from a low-wage labour market. CEP Discussion Paper No. 857, Centre for Economic Performance, London School of Economics.

Kanbur, R. (2010). Conceptualising informality: Regulation and enforcement. Indian Journal of Labour Economics, forthcoming.

Kramarz, F. and Philippon, T. (2001). The impact of differential payroll tax subsidies on minimum wage employment. Journal of Public Economics, 82, 115-146.

Krishna, P., Mitra, D. and Chinoy, S. (2002). Trade liberalization and labor-demand elasticities: Evidence from Turkey. Journal of International Economics, 55, 391-409.

Kugler, A., Jimeno, J.F. and Hernanz, V. (2003). Employment consequences of restrictive permanent contracts: Evidence from Spanish labor market reforms. CEPR Working Paper No. 3724.

Lemos, S. (2009). Minimum wage effects in a developing country. Labour Economics, 16, 224-237.

Linneman, P. (1982). The economic impacts of minimum wage laws: A new look at an old question. Journal of Political Economy, 90, 443-469.

Maloney, W. and Nuñez Mendez, J. (2004). Measuring the impact of minimum wages: Evidence from Latin America. In Heckman, J. and Pagés, C. (eds), Law and employment: Lessons from Latin America and the Caribbean. Cambridge, MA: National Bureau of Economic Research.

Neumark, D. and Wascher, W.L. (2007). Minimum wages and employment. Foundations and Trends in Microeconomics, 3, 1-182. 
Organisation for Economic Co-operation and Development (1999). OECD economic surveys: Turkey. Paris: OECD.

Ozturk, O.D. (2009). Employment effects of minimum wages in inflexible labor markets. MPRA Paper No. 16233, Munich Personal RePEc Archive, Munich.

Rebitzer, J.B. and Taylor, L.J. (1995). The consequences of minimum wage laws: Some new theoretical ideas. Journal of Public Economics, 56, 245-255.

Strobl, E. and Walsh, F. (2003). Minimum wages and compliance: The case of Trinidad and Tobago. Economic Development and Cultural Change, 51, 427-450.

Tunal1, İ. (2009). Analysis of attrition patterns in the Turkish Household Labor Force Survey, 2000-2002. In Kanbur, R. and Svejnar, J. (eds), Labor markets and development. London: Routledge.

Wellington, A. (1991). Effects of the minimum wage on the employment status of youths: An update. Journal of Human Resources, 26, 27-46. 


\section{Appendix}

Table A1

Means for the full HLFS sample

\begin{tabular}{|l|c|c|c|}
\hline Variable & Total sample & Bound workers & Unbound workers \\
\hline Age & 33.208 & 30.488 & 33.422 \\
Male & 0.796 & 0.761 & 0.799 \\
Urban & 0.777 & 0.774 & 0.777 \\
Married & 0.713 & 0.645 & 0.719 \\
Primary education & 0.410 & 0.509 & 0.402 \\
Secondary education & 0.397 & 0.440 & 0.393 \\
Tertiary education & 0.178 & 0.040 & 0.188 \\
Employed in registered job & 0.689 & 1 & 0.664 \\
Gross monthly income & $717,081,075 \mathrm{TL}$ & $314,031,277 \mathrm{TL}$ & $748,750,528 \mathrm{TL}$ \\
\hline Number of observations & 162,959 & 9,793 & 153,166 \\
\hline
\end{tabular}

Notes: The samples are restricted to those aged 16-64 who are employed and use the HLFS sampling weights, adjusted so that the total weight in each quarter is the same.

The fourth quarter of each year is excluded, as observations from these quarters can never be matched to a later quarter.

The age restrictions do not agree with those in the regression sample exactly, as the latter uses those aged 16-64 as of the second quarter a person is observed, not the first quarter. 
Table A2

Estimates of equations for usual weekly hours worked on secondary job

\begin{tabular}{|c|c|c|c|c|}
\hline Variables & \multicolumn{2}{|c|}{ Employed } & \multicolumn{2}{|c|}{ Employed in same main job } \\
\hline & $\begin{array}{c}\text { (i) } \\
\text { Hours on any work }\end{array}$ & \begin{tabular}{|c|} 
(ii) \\
Hours on paid work
\end{tabular} & $\begin{array}{c}\text { (iii) } \\
\text { Hours on any work }\end{array}$ & \begin{tabular}{|c|} 
(iv) \\
Hours on paid work
\end{tabular} \\
\hline \multicolumn{5}{|c|}{ Single treatment variable } \\
\hline Total cost gap & $\begin{array}{l}-3.372 \\
(2.362) \\
\end{array}$ & $\begin{array}{l}-2.325 \\
(2.254)\end{array}$ & $\begin{array}{l}-4.032 \\
(2.501) \\
\end{array}$ & $\begin{array}{l}-2.900 \\
(2.391) \\
\end{array}$ \\
\hline \multicolumn{5}{|c|}{ Separate treatment variables } \\
\hline $\begin{array}{l}\text { Minimum wage } \\
\text { cost gap } \\
\text { Contribution base } \\
\text { cost gap }\end{array}$ & $\begin{array}{c}-8.724 * * \\
(4.333) \\
-0.310 \\
(3.146) \\
\end{array}$ & $\begin{array}{c}-8.187 * * \\
(4.135) \\
1.029 \\
(3.002) \\
\end{array}$ & $\begin{array}{c}-9.948 * * \\
(4.616) \\
-0.747 \\
(3.301) \\
\end{array}$ & $\begin{array}{c}-9.316^{* *} \\
(4.413) \\
0.679 \\
(3.156) \\
\end{array}$ \\
\hline $\begin{array}{l}\text { Number of } \\
\text { observations }\end{array}$ & 50,287 & 50,287 & 46,857 & 46,857 \\
\hline
\end{tabular}

Notes: All regressions also include age and dummies for sex, urban status, marital status, education level ( 2 variables), whether it is three quarters since the previous observation, whether previously employed in a registered job and quarter (12 variables).

Standard errors are presented in parentheses. $*, * *$ and $* * *$ denote significance at the $10 \%, 5 \%$ and $1 \%$ level, respectively.

Regressions use HLFS sampling weights, adjusted so that the total weight in each quarter is the same. 
Table A3

Estimates of employment equations using changes in the contribution ceiling

\begin{tabular}{|c|c|c|c|c|}
\hline \multirow[t]{2}{*}{ Variable } & \multicolumn{2}{|c|}{ Employed } & \multicolumn{2}{|c|}{ Employed in same job } \\
\hline & $\begin{array}{c}\text { (i) } \\
\text { All workers }\end{array}$ & $\begin{array}{c}\text { (ii) } \\
\text { High-wage } \\
\text { workers } \\
\end{array}$ & $\begin{array}{c}\text { (iii) } \\
\text { All workers }\end{array}$ & $\begin{array}{c}\text { (iv) } \\
\text { High-wage } \\
\text { workers } \\
\end{array}$ \\
\hline Total cost gap & $\begin{array}{l}-0.756^{* * *} \\
(0.253)\end{array}$ & $\begin{array}{c}-0.460 * * \\
(0.191)\end{array}$ & $\begin{array}{l}-0.804 * * * \\
(0.273)\end{array}$ & $\begin{array}{c}-0.619 * * * \\
(0.205)\end{array}$ \\
\hline Age & $\begin{array}{l}-0.002 * * * \\
(0.000)\end{array}$ & $\begin{array}{l}-0.002 * * * \\
(0.000)\end{array}$ & $\begin{array}{l}-0.000 \\
(0.000)\end{array}$ & $\begin{array}{l}-0.001 * * * \\
(0.000)\end{array}$ \\
\hline Male & $\begin{array}{c}0.111 * * * \\
(0.004)\end{array}$ & $\begin{array}{c}0.070 * * * \\
(0.007)\end{array}$ & $\begin{array}{l}0.094 * * * \\
(0.004)\end{array}$ & $\begin{array}{c}0.056 * * * \\
(0.007)\end{array}$ \\
\hline Urban & $\begin{array}{c}0.023 * * * \\
(0.004)\end{array}$ & $\begin{array}{l}-0.005 \\
(0.007)\end{array}$ & $\begin{array}{c}0.006 \\
(0.004)\end{array}$ & $\begin{array}{l}-0.014^{*} \\
(0.007)\end{array}$ \\
\hline Married & $\begin{array}{c}0.021 * * * \\
(0.004)\end{array}$ & $\begin{array}{c}0.036 * * * \\
(0.008)\end{array}$ & $\begin{array}{l}0.026^{* * *} \\
(0.005)\end{array}$ & $\begin{array}{c}0.046 * * * \\
(0.008)\end{array}$ \\
\hline Secondary education & $\begin{array}{c}0.055^{* * *} \\
(0.004)\end{array}$ & $\begin{array}{c}0.100 * * * \\
(0.007)\end{array}$ & $\begin{array}{c}0.065 * * * \\
(0.004)\end{array}$ & $\begin{array}{c}0.114 * * * \\
(0.007)\end{array}$ \\
\hline Tertiary education & $\begin{array}{c}0.133 * * * \\
(0.005)\end{array}$ & $\begin{array}{c}0.146 * * * \\
(0.007)\end{array}$ & $\begin{array}{c}0.152 * * * \\
(0.005)\end{array}$ & $\begin{array}{c}0.158 * * * \\
(0.008)\end{array}$ \\
\hline $\begin{array}{l}\text { Three quarters since previous } \\
\text { observation }\end{array}$ & $\begin{array}{c}-0.059 * * * \\
(0.006)\end{array}$ & $\begin{array}{c}-0.073 * * * \\
(0.009)\end{array}$ & $\begin{array}{c}-0.056^{* * *} \\
(0.006)\end{array}$ & $\begin{array}{c}-0.074 * * * \\
(0.010)\end{array}$ \\
\hline Previously in registered job & $\begin{array}{c}0.195 * * * \\
(0.004)\end{array}$ & $\begin{array}{c}0.210 * * * \\
(0.009)\end{array}$ & $\begin{array}{c}0.243 * * * \\
(0.004)\end{array}$ & $\begin{array}{c}0.302 * * * \\
(0.010)\end{array}$ \\
\hline R-squared & 0.106 & 0.113 & 0.121 & 0.136 \\
\hline Number of observations & 61,723 & 14,809 & 61,641 & 14,791 \\
\hline
\end{tabular}

Notes: All regressions include dummy variables for each quarter (12 variables).

Standard errors are presented in parentheses. *,** and *** denote significance at the $10 \%, 5 \%$ and $1 \%$ level, respectively.

Regressions use HLFS sampling weights, adjusted so that the total weight in each quarter is the same. 